\title{
Factors Influencing the Presence of Papilla between Adjacent Implants and between a Tooth and an Implant
}

\section{Čimbenici koji utječu na prisutnost papile između susjednih implantata i između zuba i implantata}

\author{
${ }^{1}$ Federal University of Pernambuco, Recife, Pernambuco, Brazil. \\ Savezno sveučilište u Pernambucu, Recife, Pernambuco, Brazil \\ 2 Student Graduate Dentistry, Federal University of Pernambuco, Recife, Pernambuco, Brazil. \\ Student dentalne medicine na Saveznom sveučilištu u Pernambucu, Recife, Pernambuco, Brazil \\ ${ }^{3}$ University of Pernambuco, Camaragibe, Pernambuco, Brazil. \\ Sveučilište u Pernambucu, Camaragibe, Pernambuco, Brazil
}

\section{Abstract}

Aim: The aim this study was to evaluate the factors that influence the presence or absence of the interproximal papilla between implants adjacent to the teeth or other implants, through clinical and radiographic evaluation. Material and Methods: The non-probabilistic sample comprised 44 patients of both genders aged between 21 and 68 years, rehabilitated with 114 osseointegrated implants. Through a retrospective clinical study, the patients were divided according to the presence or absence of the interproximal papilla: Group 1 - Absence of Papilla, Group 2 - Partial Presence of Papilla and Group 3 - Total Presence of Papilla. The success of the implants, the periodontal biotype, and the vertical and horizontal distances of the interproximal regions included in the study were evaluated. Results: Of the 114 implants, $46.5 \%$ were considered unsuccessful, and bleeding was present in $29.8 \%$. The periodontal biotype presented as thin and scalloped was found in $85.1 \%$ of the regions. The evaluation of the groups according to the confirmation of the interproximal space showed a statistically significant difference $(p=0.007)$, with $61.9 \%$ of the wide and long interproximal spaces classified as Group 1, while 31\% of the narrow and short interproximal spaces were classified as Group 3. Conclusion: It was concluded that the morphology of the interproximal space was the factor that was most strongly associated with the presence or absence of the interproximal papilla.
Received: June 16, 2019

Accepted: October 29, 2019

Address for correspondence

Renata Cimões

University Cidade

Recife 50670-901, Brazil

Av. Prof. Moraes Rego, 1235

Tel: +558121268817

renata.cimoes@globo.com

Key words

Dental Implants; Gingiva; Dental Esthetics

\section{Introduction}

In dentistry, increased esthetic demands require a soft-tissue contour with an intact papilla and a symmetric gingival outline (1). Ideally, successful implant-supported restorations have an appearance as close as possible to natural teeth (2). Color, texture, and peri-implant soft tissue height and thickness play a fundamental role in the implant restorations outcome (3).

A successful bony integration of an implant does not ensure full patient satisfaction. Soft tissue health is critical to the patient's perception of a successful restoration (4). Currently, there is an increasing concern about the smile esthetics from patients seeking dental treatment. The presence or absence of the interproximal papilla between adjacent teeth, between a tooth and an implant, or between implants strongly influence the esthetic outcome, which demands a high level of skill and technical knowledge of the professionals to preserve the papilla in implant treatments (5).

The papilla is characterized as an interproximal extension of the gingiva and its architecture is related to the condition
Uvod

U dentalnoj medicini povećani estetski zahtjevi traže kao ideal konture mekoga tkiva s intaktnim papilama i simetričnim obrisom gingive (1). U idealnom slučaju uspješne implantoprotetičke restauracije izgledaju što je moguće sličnije prirodnim zubima (2). Boja, tekstura, visina i debljina periimplantatnog mekog tkiva najvažniji su u postizanju rezultata s restauracijama na implantatima (3).

Uspješna oseointegracija implantata ne jamči zadovoljstvo pacijenata. Za njihovu percepciju uspješne restauracije presudno je zdravlje mekoga tkiva (4). Danas je kod pacijenata koji dolaze radi terapije sve veći naglasak na estetici osmijeha. Prisutnost ili odsutnost interproksimalne papile između susjednih zuba, između zuba i implantata ili između dvaju implantata snažno utječu na estetski ishod, što zahtijeva visoku razinu vještine i stručnog znanja kliničara kako bi očuvao papile u sklopu implantoprotetičke terapije (5).

Papila je interproksimalni produžetak gingive, a njezina arhitektura povezana je sa stanjem kontaktne točke između 
of the contact point between the teeth as well as to the course of the cementum-enamel junction (6). Furthermore, understanding the factors that are most strongly associated with the formation of the interdental papilla will decrease the peri-implantitis risk ratio and will be important for treatment planning and prognosis (7).

The appearance and presence of the papilla may be influenced by a number of factors such as underlying bone structure, adjacent soft tissue quality, the shape of the restoration, the contact point between the crowns, dental positioning in the arch, and periodontal / peri-implant phenotype (8-10).

Since soft-tissues have become an important factor in the overall success of a large number of implant-supported restorations, the loss of the peri-implant papilla leads to an esthetic disadvantage known as the black triangle. Currently, one of the most challenging aspects of periodontal reconstructive surgery is to obtain a suitable peri-implant papilla in the esthetic area (11). The existence of space below the contact area can lead not only to compromised esthetics but also to phonetic problems, periodontal diseases, and food impaction $(12,13)$. The peri-implant soft tissue condition appears to be a critical determinant for the occurrence of this undesirable space (14).

In natural teeth, the height of the interproximal papilla is influenced by the position of the contact point between teeth and the level of the proximal bone crest. For single implants, similar findings were observed. A completely filled papilla is expected when the distance from the contact point to the proximal bone crest is less than $5 \mathrm{~mm}(12,15,16)$.

Some studies correlating the importance of the distance from the bone crest to the contact point of adjacent tooth crowns and implants were performed, as well as the studies correlating the distance between an implant and tooth and between implants in the presence of papilla. From these parameters, greater predictability can be obtained in the formation of the interproximal papilla in the rehabilitations. In addition to the vertical distance, the horizontal distance between adjacent implants when smaller than $3 \mathrm{~mm}$ determined the absence of interproximal papilla, independent of the vertical distance. When this distance is greater than or equal to $3 \mathrm{~mm}$ there is an interaction between the vertical and horizontal distances. In the interproximal areas with implant adjacent to the tooth, this horizontal distance can reach $1.5 \mathrm{~mm}$, considering that the presence of dental structures exerts a greater influence on the formation of the papilla. In relation to prognosis in the peri-implant papilla formation, it was evident that it is related to the peri-implant bone height and the contact point $(5,17,18)$.

The interproximal papilla morphology and the bone architecture that houses the tooth can be categorized into two periodontal biotypes (19-21). The first periodontal biotype is the scalloped periodontium, characterized by thin gingival tissue and long interproximal papilla. The second periodontal biotype is the flat periodontium, which is characterized by a flat morphology, bone structure and thick gingival tissue and short and wide papilla. Individuals with the thin periodontal biotype may have more soft tissue recession than those with the flat and thick periodontal biotype (21). zuba i tijekom caklinsko-cementnoga spojišta (6). Nadalje, razumijevanje čimbenika koji su najpovezaniji sa stvaranjem interdentalne papile smanjit će rizik od perimplantitisa, što je važno za planiranje i prognozu liječenja (7).

$\mathrm{Na}$ izgled i prisutnost papile može utjecati niz čimbenika kao što su osnovna struktura kosti, kvaliteta susjednih mekih tkiva, oblik restauracije, položaj kontakta između krunica, položaj zuba u luku i fenotip parodontnog/periimplantatnog tkiva $(8-10)$.

Budući da su meka tkiva postala važan čimbenik u ukupnom uspjehu većine restauracija na implantatima, gubitak periimplantatne papile rezultira estetskim deficitom poznatim kao crni trokut. Danas je jedan od najizazovnijih aspekata parodontne rekonstruktivne kirurgije predvidivo dobivanje periimplantatnih papila u estetskom području (11) Prazan prostor ispod kontaktnih područja može dovesti ne samo do estetskog kompromisa, nego i do fonetskih problema, parodontnih bolesti i ulaska hrane $(12,13)$. Čini se da je stanje periimplantatnog mekog tkiva presudna odrednica za pojavu toga nepoželjnoga praznog prostora (14).

Kod prirodnih zuba na visinu interproksimalne papile utječe položaj kontaktne točke između zuba i razina interdentalnog koštanog grebena. Za pojedinačne implantate uočeni su slični nalazi. Potpuna ispunjenost papilom očekuje se kada je udaljenost od kontaktne točke do interproksimalnog koštanog grebena manja od $5 \mathrm{~mm}(12,15,16)$.

Provedena su istraživanja u kojima je analizirana važnost udaljenosti od koštanog grebena do mjesta kontakta susjednih krunica i implantata, zatim udaljenost između implantata i zuba te između implantata u prisutnosti papile. Na temelju tih parametara može se postići veća predvidivost nastanka interproksimalne papile. Uz vertikalnu udaljenost, horizontalna udaljenost između susjednih implantata manja od 3 mm određuje odsutnost interproksimalne papile, neovisno o vertikalnoj udaljenosti. Kad je ta udaljenost veća ili jednaka $3 \mathrm{~mm}$, postoji vertikalna i horizontalna interakcija. $U$ interproksimalnim područjima s implantatom u susjedstvu zuba ta horizontalna udaljenost može iznositi $1,5 \mathrm{~mm}$ s obzirom na to da zubne strukture imaju veći utjecaj na stvaranje papile. U odnosu prema prognozi stvaranja periimplantatne papile, utvrđena je povezanost $s$ visinom periimplantatne kosti i kontaktne točke $(5,17,18)$.

Morfologija interproksimalne papile i koštana arhitektura oko zuba mogu se svrstati u dva parodontna biotipa (19 - 21). Prvi karakterizira tanko gingivno tkivo, a dugi interproksimalne papile $s$ valovitim tijekom gingive. Drugi parodontni biotip ima ravnu morfologiju, jaku kost i debelo gingivno tkivo te kratku i široku papilu. Pojedine osobe s tankim parodontnim biotipom mogu imati više recesija mekoga tkiva od onih s ravnim i debelim biotipom parodonta (21).

Cilj je ovog istraživanja bio procijeniti klinički i radiološki čimbenike koji utječu na prisutnost ili odsutnost interproksimalne papile između susjednih implantata te između zuba i implantata. 
The present study aimed to assess the factors that influence the presence or absence of the interproximal papilla between adjacent implants, and between tooth and implant, through clinical and radiographic evaluation.

\section{Material and Methods}

This study was approved by the Research Ethics Committee of the Health Sciences Center of the Federal University of Pernambuco (CCS-UFPE) under the CAAE 03534012.0.0000.5208, Opinion 84041. All individuals consented to the data collection by signing an Informed Consent.

A retrospective clinical study was performed with patients rehabilitated with osseointegrated implants in the Specialization Course in Implantology at the Federal University of Pernambuco (UFPE) from 2011 to 2015. The non-probabilistic sample comprised 44 patients, rehabilitated with 114 implants. Each patient was evaluated only once during this study.

Inclusion criteria were: the presence of at least one dental implant with a prosthetic crown in function for more than one year and those over 18 years of age. Exclusion criteria were: use of medications that act on bone remodeling (i.e., bisphosphonates) or interfere with the gingival condition (i.e., calcium channel blockers), history of periodontitis, pregnancy or lactation, immunosuppression, history of soft tissue graft surgery at the implant site, and the absence of the contact point between the crowns of the implant regions evaluated.

\section{Clinical and radiographic evaluation}

All the patients' health histories were reviewed and submitted to the extra-oral and the intra-oral examination. In the course of intra-oral examination, the periodontal condition was recorded in a periogram previously calibrated using the North Carolina periodontal probe (Trinity ${ }^{\circ}$, São Paulo, Brazil), by a single examiner and the following parameters were evaluated and recorded: Plaque Index (PI), (23), Bleeding Index (BI), (23), Gingival Recession (GR), Probing Depth (PD), and Periodontal Attachment Level (PAL).

To evaluate the integration success of the implants placed, the criteria described by Ong et al. (24) which grouped several authors' definitions, were used: the absence of mobility, the absence of persistent subjective complaints (pain, foreign body sensation and / or dysesthesia, the absence of recurrent peri-implant infection with suppuration, the absence of continuous radiolucency around the implant, the absence of probing depth greater than or equal to $5 \mathrm{~mm}$, and the absence of bleeding on probing) (25-27). The annual vertical bone loss, mesial or distal, was not evaluated in this study due to the absence of annual radiographic records of all patients (28).

The periodontal biotype classification was determined by Olsson $\&$ Lindhe, who categorized the gingiva into two tissue biotypes (flat or scalloped) with punctual and marked differences between them (22).

After recording the clinical parameters, the papilla between adjacent implants or between implant and tooth were

\section{Materijali i metode}

Ovo istraživanje odobrio je Odbor za istraživačku etiku Centra za medicinske znanosti pri Saveznom sveučilištu u Pernambucu (CCS-UFPE) - CAAE 03534012.0.0000.5208, mišljenje 84041. Svi pojedinci pristali su na prikupljanje podataka nakon što su potpisali informirani pristanak.

Retrospektivno kliničko istraživanje provedeno je na pacijentima rehabilitiranima oseintegrirajućim implantatima u sklopu specijalizacije iz implantologije pri Federalnom sveučilištu u Pernambucu (UFPE-u) od 2011. do 2015. Uzorak je obuhvatio 44 pacijenta rehabilitirana sa 114 implantata. Svaki pacijent ocijenjen je tijekom ovog istraživanja samo jedanput.

Kriteriji za uključivanje bili su barem jedan dentalni implantat $s$ krunicom u funkciji dulje od jedne godine i dob iznad od 18 godina. Kriteriji za isključivanje bili su upotreba lijekova koji djeluju na remodeliranje kosti ( $\mathrm{tj}$. bisfosfonati) ili utječu na stanje gingive (tj. blokatori kalcijevih kanala), povijest parodontitisa, trudnoća ili dojenje, imunosupresija, transplantacija mekog tkiva na mjestu oko implantata te nepostojanje kontaktne točke između krunica u implantacijskim područjima.

\section{Klinička i radiološka procjena}

Analizirane su anamneze pacijenata i obavljeni ekstraoralni i intraoralni pregledi. Tijekom intraoralnog pregleda stanje parodonta bilježio je jedan istraživač koji je prije toga kalibriran, a koristio se parodontološkom sondom North Carolina (Trinity', São Paulo, Brazil). Sljedeći parametri koji su ocijenjeni i zabilježen jesu indeks plaka (PI) ) (23), indeks krvarenja (BI) (23), recesija gingive (GR), dubina sondiranja (PD) i razina pričrrstka (PAL).

Da bi se procijenila uspješnost ugrađenih implantata, korišteni su kriteriji Onga i suradnika (24) koji su grupirali nekoliko kriterija: odsutnost pomičnosti, odsutnost trajnih subjektivnih tegoba (bol, osjet stranog tijela i/ili disestezija), odsutnost ponavljajuće periimplantatne infekcije sa supuracijom, odsutnost kontinuirane radiolucencije oko implantata, odsutnost dubine sondiranja veće od $5 \mathrm{~mm}$ ili točno 5 $\mathrm{mm}$ i odsutnost krvarenja nakon sondiranja $(25-27)$. Godišnji vertikalni gubitak kosti, mezijalni ili distalni, nije evaluiran u ovom istraživanju zato što nije bilo godišnjih radioloških zapisa svih pacijenata (28).

Klasifikaciju parodontnog tkiva uveli su Olsson i Lindhe koji su opisali dva biotipa (ravan ili valovit) sa znakovitim razlikama između njih (22).

Nakon bilježenja kliničkih parametara, papile između susjednih implantata ili između implantata i zuba klasificirane su prema ovim autorima:

1) Jemtu (29) - njegov indeks ocjenjuje visinu papile između zuba i implantata, a prilagođeno ovom istraživanju također između susjednih implantata. 
classified according to two authors:

1) Jemt (29): this index evaluated the height of the papilla between tooth and implant, adapted for this study to classify the areas between adjacent implants as well.

2) Nordland \& Tarnow (30): this index evaluated the presence of papilla between adjacent teeth, being adapted for this study to classify the papillae between tooth and implant and between adjacent implants.

Then, the papilla between implants adjacent to tooth or another implant were categorized into 3 groups: G1 - Absence of Papilla [indexes 0 and 1 of Jemt (29) and Classes II and III of Nordland and Tarnow (30)]; G2 - Partial Papilla Presence [Jemt index 2 (29) and Class I of Nordland and Tarnow (30)]; G3 - Total Papilla Presence [indexes 3 and 4 of Jemt (29) and Normal classification of Nordland and Tarnow (30)].

With the clinical data obtained, the prognosis was determined in relation to the presence of the papilla, considering the height of the interproximal bone crest up to the contact point and it was divided into three classes, according to Salama et al. (17): Class 1: Favorable Prognosis; Class 2: Less Favorable Prognosis; Class 3: Unfavorable Prognosis.

To determine the vertical distance (distance from the peak of the alveolar crest to the base of the contact point), the methodology proposed by Tarnow et al. (12) was used. The procedure was the same for the areas between implants adjacent to the tooth or implant.

After the clinical examination and the classification of the interproximal papillae, the patient underwent a radiographic examination, standardized in a ratio of $1: 1$, periapicaly in the region of each implant, using the parallelism technique through positioners for periapical radiographs. The radiographic analysis was performed using a magnifying glass on a radiographic light to obtain the following data: presence or absence of radiolucency around the implant; horizontal distance between adjacent implants, measured from one implant platform to the other, or between tooth and implant; measurement of the implant platform at the root of the adjacent tooth at the location of cementum-enamel junction; distance from cement-enamel junction to bone crest; and distance from the apical end of the contact point to the bone crest.

Associating the already established measurement of the bone crest to the contact point and the horizontal distance between adjacent implants or between tooth and implant, the association of the morphology of the interproximal space with the presence of recession of the interproximal papilla was evaluated. Thus, the interproximal space was classified according to Table 1, (1).
2) Nordlandu i Tarnowu (30) - njihov j indeks ocjenjuje prisutnost papile između susjednih zuba, a prilagođeno ovom istraživanju papile između zuba i implantata i između susjednih implantata.

Zatim su papile između implantata i zuba ili drugog implantata razvrstane u tri skupine:

G1 - odsutnost papile [indeks 0 i 1 prema Jemtu (29) i klase II. i III. prema Nordlandu i Tarnowu (30)] G2 - djelomična prisutnost papile [Jemtov indeks 2 (29) i klasa I. prema Nordlandu i Tarnowu (30)]

G3 - potpuno prisustvo papile [indeks 3 i 4 prema Jemtu (29) i normalna klasifikacija prema Nordlandu i Tarnowu (30)].

$S$ dobivenim kliničkim podatcima prognoza je određena u odnosu prema prisutnosti papile, uzimajući u obzir visinu interproksimalnog koštanog grebena do kontaktne točke, podijeljeno u tri klase prema Salami i suradnicima (17): klasa 1. - povoljna prognoza; klasa 2. - manje povoljna prognoza; klasa 3. - nepovoljna prognoza.

Da bi se odredila vertikalna udaljenost (udaljenost od vrha alveolarnog grebena do baze kontaktne točke) primijenjena je metodologija koju su predložili Tarnow i suradnici (12). Postupak je bio jednak za područja između implantata i zuba ili implantata i implantata.

Nakon kliničkog pregleda i klasifikacije interproksimalnih papila, pacijent je podvrgnut radiološkom pregledu u standardiziranom omjeru 1:1, učinjena je periapikalna snimka područja oko svakog implantata koristeći se paralelnom tehnikom kroz pozicionere za periapikalne snimke. Analiza snimki provedena je s pomoću povećala na rendgenoskopu radi dobivanja sljedećih podataka: prisutnosti ili odsutnosti radiolucencije oko implantata, horizontalne udaljenost između susjednih implantata - mjereno od jedne platforme implantata do druge, ili između zuba i implantata, mjerenja platforme implantata na korijenu susjednog zuba na caklinsko-cementnom spojištu, udaljenosti od caklinsko-cementnog spojišta i cakline do koštanog grebena i udaljenosti od apikalnog kraja kontaktne točke do koštanog grebena.

Povezivanjem već utvrđenog mjerenja koštanog grebena $s$ kontaktnom točkom i horizontalne udaljenosti između susjednih implantata ili između zuba i implantata, procijenjena je povezanost morfologije interproksimalnog prostora s recesijom interproksimalne papile. Stoga je interproksimalni prostor klasificiran prema tablici 1. (1).

Table 1 Classification of interproximal space according to Chang, 2007.

Tablica 1. Klasifikacija interproksimalnog prostora prema Changu (2007.)

\begin{tabular}{l|l|c} 
Wide $\leq 2 \mathrm{~mm} \bullet$ Širina $\leq 2 \mathrm{~mm}$ & Height $\leq \mathbf{4 m m} \bullet$ Visina $\leq 4 \mathrm{~mm}$ & Height $>\mathbf{4 ~ m m} \bullet$ Visina $>4 \mathbf{m m}$ \\
\hline Wide $>2 \mathrm{~mm} \bullet$ Širina $>2 \mathrm{~mm}$ & Narrow ans Short $\bullet$ uski i kratki & Narrow and Long $\bullet$ uski i dugi \\
\hline
\end{tabular}




\section{Statistical analysis}

After data collection, data were expressed as mean, standard deviation, and absolute and relative frequency distributions. Continuous variables were compared by the Mann Whitney non-parametric test, since the results did not follow normal distribution, and, when it was not possible to perform the Chi-square test because the assumption of expected values below $20 \%$, in most cases the proportions were violated and a comparison was performed by the Likelihood Ratio test. The level of significance was set at P 0.05 , and the confidence level at $95 \%$. The software used was the Statistical Package of Social Science (SPSS) version 20.0 and the data were entered in Microsoft Excel.

\section{Results}

Forty-four patients were involved in the study. They were rehabilitated with 114 implants and presented 176 interproximal areas for papilla formation. Age ranged from 21 to 68 years, averaging 49 years, and $63.6 \%$ of the patients were female. The mean loading time of the implants evaluated was 32.4 months.

The periodontal biotype was classified as thin and scalloped in $85.1 \%$ of the evaluated regions. Among the criteria of Ong et al. (24), 46.5\% of implants were considered unsuccessful. Bleeding on probing showed the highest percentage with $29.8 \%$, followed by the probing depth $>5 \mathrm{~mm}$, with $28.9 \%$ (Table 2).

Of the total number of papilla evaluated, 86 belonged to Group 1 (48.9\%), 68 to Group 2 (38.6\%) and 22 to Group $3(12.5 \%)$. The evaluation of the presence of bone graft prior to implant installation was performed on 171 papillae taking into account the fact that information was not obtained for 5 papillae.

\section{Statistička analiza}

Nakon prikupljanja podatci su izraženi kao srednja vrijednost, standardna devijacija te apsolutna i relativna frekvencija. Kontinuirane varijable usporedivale su se neparametrijskim Mann-Whitneyjevim testom jer nisu pratile normalnu distribuciju, a usporedba proporcija obavljena je testom omjera vjerojatnosti kada Chi-kvadrat test nije bio primjenjiv zato što je bila prekršena njegova pretpostavka o očekivanim vrijednostima manjima od $20 \%$ u većini slučajeva. Razina značajnosti postavljena je na $\mathrm{P}=0,05$, a razina pouzdanosti na $95 \%$. Korišteni softver bio je statistički paket za društvene znanosti (SPSS), verzija 20,0, a podatci su uneseni u Microsoft Excel.

\section{Rezultati}

$\mathrm{U}$ istraživanju su analizirana četrdeset i četiri pacijenta. Ugrađeno je 114 implantata sa 176 interproksimalnih područja za formiranje papile. Dob ispitanika bila je u rasponu od 21 do 68 godina, (prosječno 49 godina), a 63,6 \% bile su žene. Procijenjeno prosječno vrijeme opterećenja implantata bilo je 32,4 mjeseca.

Parodontni biotip klasificiran je kao tanak i valovit u 85,1 $\%$ evaluiranih regija. Prema kriteriju Onga i suradnika (24), $46,5 \%$ implantata smatralo se neuspješnima. Krvarenje pri sondiranju bila je najčešća komplikacija s 29,8 \%, a slijedi dubina sondiranja $>5 \mathrm{~mm} \mathrm{~s} 28,9 \%$ (tablica 2).

Od ukupnog broja procijenjenih papila, 86 je pripadalo prvoj skupini (48,9\%), 68 drugoj (38,6 \%) i 22 trećoj $(12,5$ $\%)$. Procjena prisutnosti koštanoga grafta prije ugradnje implantata učinjena je na samo 171 papili s obzirom na to da nisu dobiveni podatci za 5 papila.

Razlike između skupina bile su statistički značajne za položaj papile i za područje u luku (tablica 3.).

Table 2 Implants success classification according to Ong et. al. (2008) criteria.

Tablica 2. Klasifikacija uspješnosti terapije implantatima prema Ongu i suradnicima (2008.)

\begin{tabular}{|c|c|c|}
\hline Implants $\bullet$ Implantati & $\mathbf{N}$ & $\%$ \\
\hline \multicolumn{3}{|l|}{ Mobility $\bullet$ Mobilnost } \\
\hline Yes $\bullet \mathrm{Da}$ & 1 & 0.9 \\
\hline \multicolumn{3}{|l|}{ Subjective complaints $\bullet$ Subjektivne tegobe } \\
\hline Yes $\bullet \mathrm{Da}$ & 2 & 1.8 \\
\hline $\mathrm{No} \cdot \mathrm{Ne}$ & 112 & 98.2 \\
\hline \multicolumn{3}{|l|}{ Inffection with supuration $\bullet$ Infekcija sa supuracijom } \\
\hline Yes $\bullet \mathrm{Da}$ & 2 & 1.8 \\
\hline $\mathrm{No} \cdot \mathrm{Ne}$ & 112 & 98.2 \\
\hline \multicolumn{3}{|l|}{ Radiolucency $\bullet$ Radiolucencija } \\
\hline Yes $\bullet \mathrm{Da}$ & 1 & 0.9 \\
\hline $\mathrm{No} \cdot \mathrm{Ne}$ & 113 & 99.1 \\
\hline Yes $\bullet \mathrm{Da}$ & 33 & 28.9 \\
\hline $\mathrm{No} \cdot \mathrm{Ne}$ & 81 & 71.1 \\
\hline \multicolumn{3}{|l|}{ Bleeding on Probing • Krvarenje nakon sondiranja } \\
\hline Yes $\bullet \mathrm{Da}$ & 34 & 29.8 \\
\hline $\mathrm{No} \cdot \mathrm{Ne}$ & 80 & 702 \\
\hline Total • Ukupno & 114 & 100.0 \\
\hline
\end{tabular}


Table 3 Group distribution according to the variables of interest.

Tablica 3. Distribucija po skupinama u odnosu prema promatranim varijablama

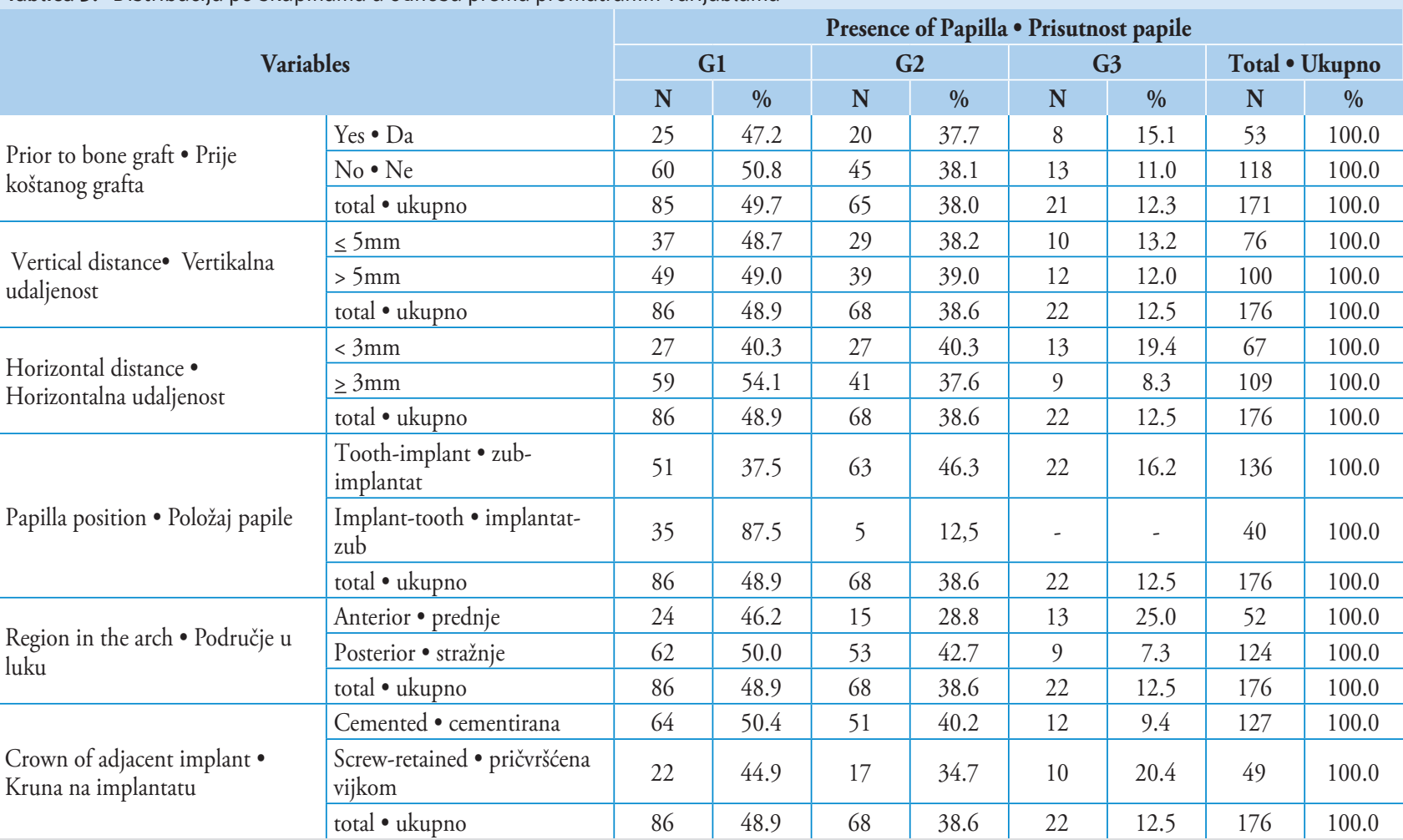

1- Pearson Chi-square test $\bullet$ Pearsonov Chi-kvadrat test

Table 4 Distribution of the papilla presence according to variables of interest.

Tablica 4. Distribucija prisutnosti papile u odnosu prema promatranoj varijabli

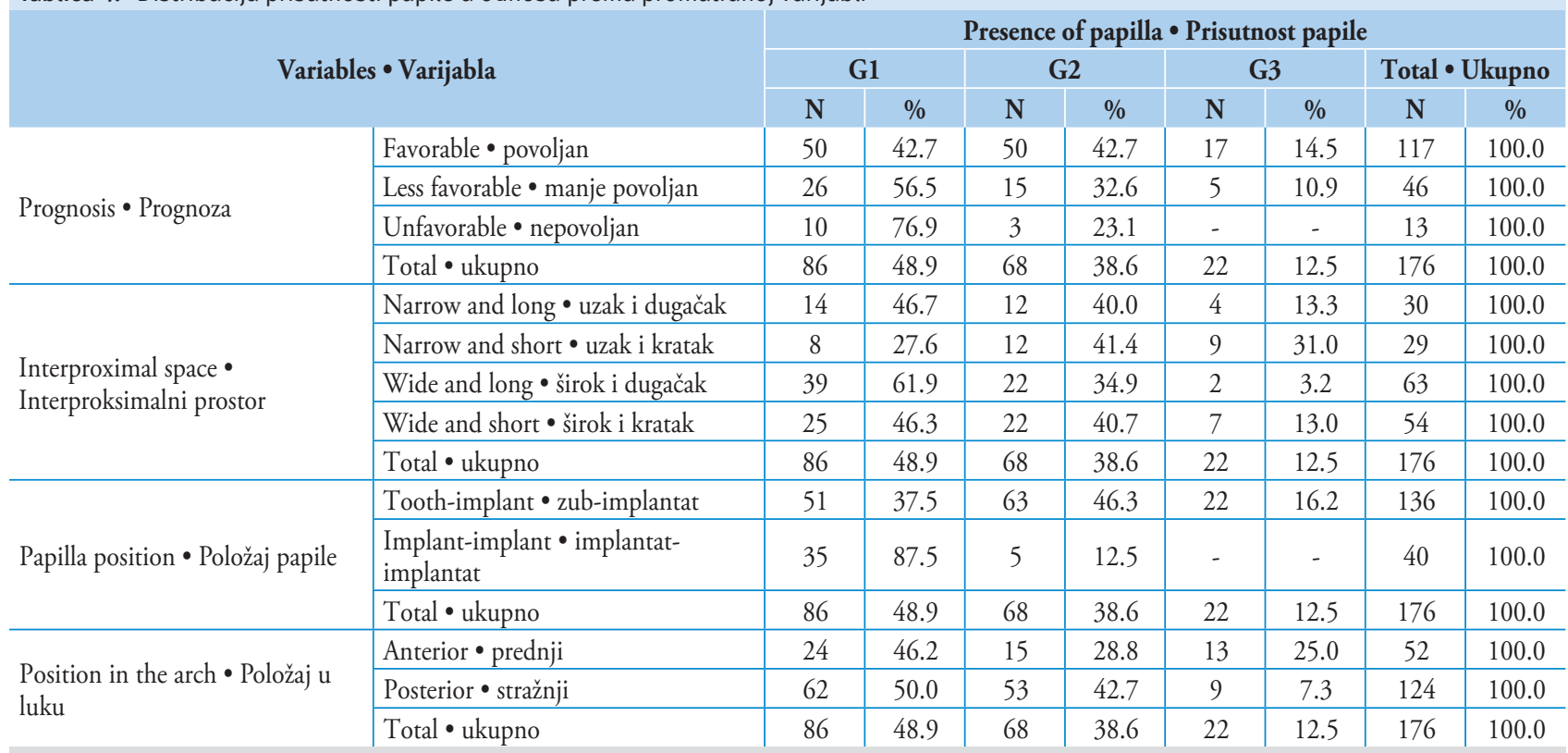

1- Pearson Chi-square test $\bullet$ Pearsonov Chi-kvadrat test

The differences between the groups were statistically significant for the position of the papilla and for the region of the papilla in the arch (Table 3).

The evaluation of the groups showed a statistically significant difference for the conformation of the interproximal space, revealing that $61.9 \%$ of spaces classified as wide and
Procjena skupina pokazala je statistički značajnu razliku za konformaciju interproksimalnog prostora, pri čemu je $61,9 \%$ širokih i dugih prostora pripadalo prvoj skupini formiranja papile, a $31 \%$ uskih i kratkih prostora ubrajalo se u treću skupinu. P-vrijednost također je bila statistički značajna za položaj papile, pri čemu papila nije bila potpuno formi- 
long belonged to Group 1, while 31\% of the narrow and short spaces had papilla of Group 3. The p-value was also statistically significant for the position of the papilla, noting that papilla was not completely formed in the interproximal regions between adjacent implant. Considering the position in the arch, $50 \%$ of posterior interproximal regions with total absence of papilla were found (Table 4).

Evaluating the interproximal regions between the tooth and the implant, we observed a statistically significant difference between the groups for prognosis, interproximal space and position in the arch. For regions between adjacent implants, these differences were not significant between the groups (Tables 4 and 5). rana u interproksimalnim područjima između susjednih implantata. Uzimajući u obzir položaj papile u luku, utvrđeno je da je $50 \%$ stražnjih interproksimalnih područja bilo potpuno bez papile (tablica 4.).

Procjenjujući interproksimalne regije između zuba i implantata, utvrđena je statistički značajna razlika između skupina za prognozu, konfiguraciju interproksimalnog prostora i položaj u luku. Te razlike među skupinama nisu bile značajne za regije između susjednih implantata (tablice 4 i 5 ).

Table 4 Distribution of the groups of papilla between implant and tooth according to variables of interest.

Tablica 4. Distribucija prisutnosti papile između implantata i zuba u odnosu prema promatranim varijablama

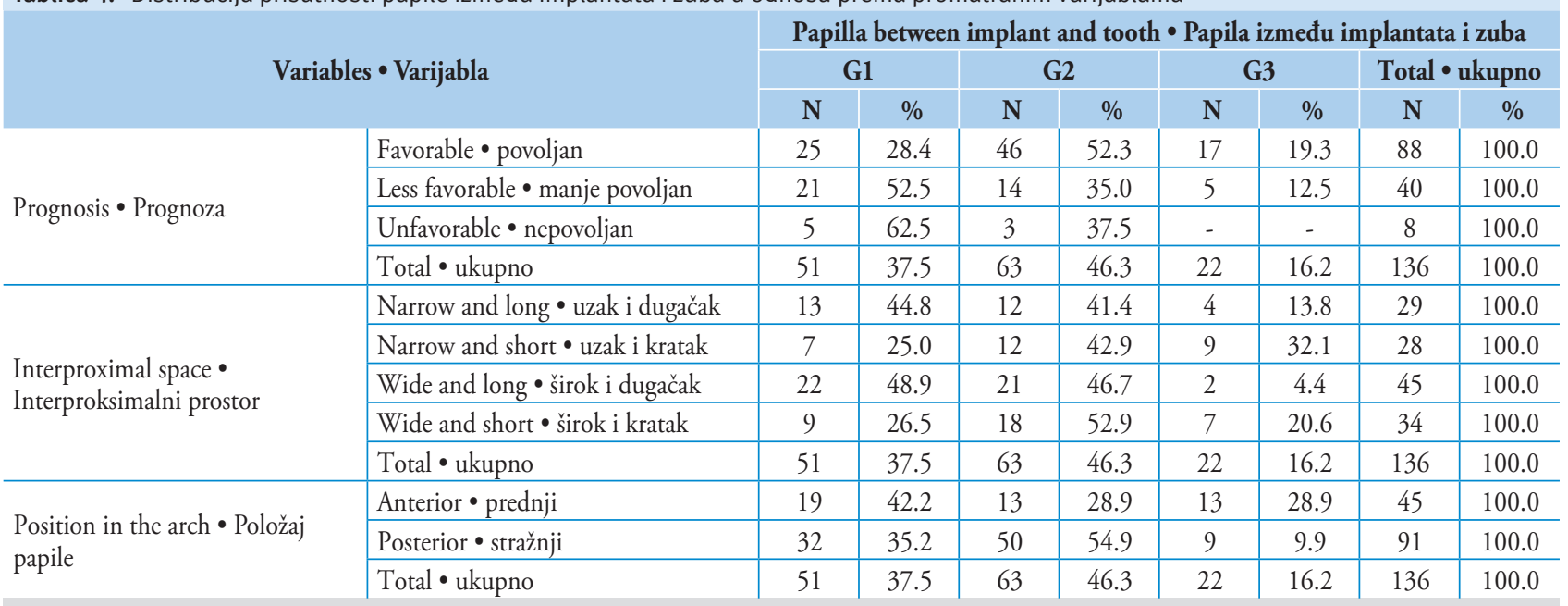

1-Likelihood Ratio test $\bullet$ test omjera vjerojatnosti; 2-Pearson Chi-square test $\bullet$ Pearsonov Chi-kvadrat test

Table 5 Distribution of the groups of papilla between adjacent implants according to variables of interest.

Tablica 5. Distribucija prisutnosti papile između susjednih implantata u odnosu prema promatranim varijablama

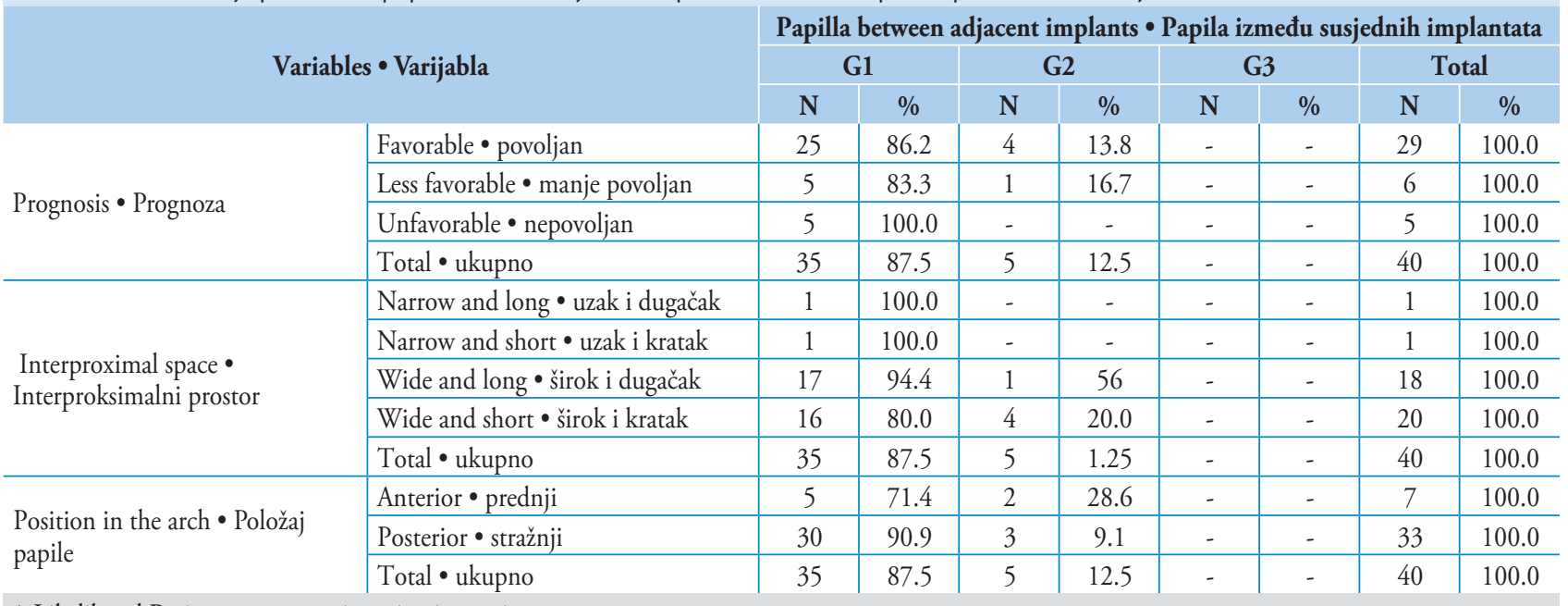

1-Likelihood Ratio test $\bullet$ test omjera vjerojatnosti 


\section{Discussion}

The maintenance of soft tissue harmony after rehabilitation with dental implants constitutes a major challenge for modern dentistry. The focus of several studies is the interproximal papilla which is responsible for filling the space between dental crowns and should be present from the base of the contact point to the bone crest, which is considered to be a true papilla $(31,32)$.

Several studies demonstrate the difficulty in achieving the formation of a true papilla after a tooth loss and the rehabilitation of this space through osseointegrated implants. Moreover, in regions between adjacent implants, this difficulty is increased by the absence of important dental anatomical structures, such as the cement-enamel junction, which guides the papilla formation (11). This can be observed in the results of this study, in which, although respecting the horizontal and vertical distances recommended in the literature, all regions between adjacent implants did not present completely formed papilla. Furthermore, when some researchers compared the presence of the interproximal papilla between different regions, the regions between adjacent implants obtained the less satisfactory results (33).

The implants evaluated in this study obtained $46.5 \%$ of failure, according to the criteria grouped by Ong et al. (24) and bleeding was the most present factor of failure (29.8\%). These results may demonstrate transitory conditions associated with other factors, such as poor oral hygiene.

Restoring the interproximal papilla is difficult when there is no natural tooth involved. In this scenario, a short papilla should be expected and implant-supported restorations demonstrate poorer results (33). In this study, it was observed that almost half (48.9\%) of the evaluated regions did not have interproximal papilla.

The presence of a thin and scalloped periodontal biotype contributes to a higher rate of papilla loss, due to the fact that this periodontal biotype is more susceptible to recessions $(22,34)$. It was observed in this study that $85.1 \%$ of the periodontal biotype in the regions of the implants evaluated was classified as thin, which may contribute to the absence of the papilla.

The prognosis for the presence of papilla proposed by Salama et al. (17) was not compatible with the presence of interproximal papilla in this study. This may be associated to the fact that this prognosis uses only the vertical distance as criteria, whereas, for the sample used in this study, the association of this distance with the horizontal distance was the determinant because both the anterior region and the posterior region were evaluated such as implants adjacent to teeth or to another implant.

The studies by Tarnow et al. (12) and Cho et al. (31) showed that when the distance from the contact point to the bone crest was $\leq 5 \mathrm{~mm}$, the interproximal papilla was always present. In this study, it was observed that this did not apply to the regions between adjacent implants and between the tooth and the implant, since $48.7 \%$ of the regions that had vertical distance $<5 \mathrm{~mm}$ did not present papilla formation. Thus, the importance of dental structures for the formation

\section{Rasprava}

Sačuvati skladnost mekih tkiva nakon implantoprotetske terapije glavni je izazov suvremene dentalne medicine. Interproksimalna papila koja je u fokusu nekoliko istraživanja odgovorna je za popunjavanje prostora između krunica i trebala bi se protezati od baze kontaktne točke do koštanog grebena kako bi se smatrala pravom papilom $(31,32)$.

U nekoliko istraživanja ističu se poteškoće u stvaranju prave papile nakon gubitka zuba i njegova nadomještanja oseintegrirajućim implantatima. Štoviše, u regijama između susjednih implantata ta se poteškoća povećava jer ne postoje važne anatomske strukture, poput caklinsko-cementnog spojišta, koje bi usmjeravale oblikovanje papile (11). To se može primijetiti u rezultatima ovog istraživanja u kojemu, iako su poštovane horizontalne i vertikalne udaljenosti preporučene u literaturi, sve regije između susjednih implantata nisu imale potpuno formirane papile. Nadalje, drugi su autori također istaknuli taj nalaz kada su uspoređivali prisutnost interproksimalne papile između različitih regija i regija između susjednih implantata gdje su dobili manje zadovoljavajuće rezultate (33).

$\mathrm{Na} 46,5 \%$ implantata u ovom istraživanju otkriven je neki pokazatelj neuspjeha prema kriterijima Onga i suradnika (24), a krvarenje je bio najzastupljeniji čimbenik zatajenja $(29,8 \%)$. Ovi rezultati mogu upućivati i na prolazne uvjete povezane s drugim čimbenicima, kao što je loša oralna higijena.

Obnavljanje interproksimalne papile otežano je ako ne postoji prirodni zub. U tom slučaju treba očekivati kratku papilu, a restauracije na implantatima pokazuju lošije rezultate (33). U ovom istraživanju uočeno je da gotovo polovina $(48,9 \%)$ procijenjenih regija nije imala interproksimalnu papilu.

Tanak i valovit parodontni biotip pogoduje većoj stopi gubitka papile zbog činjenice da je podložniji recesiji (22, 34). U ovom istraživanju zapaženo je da je u $85,1 \%$ slučajeva parodontni biotip u procijenjenim regijama klasificiran kao tanak, što može pridonijeti odsutnosti papile.

Prognoza za prisutnost papile koju su predložili Salama i suradnici (17) nije bila kompatibilna s nalazima u ovom istraživanju. To se može pripisati činjenici da se u toj prognozi koristila samo vertikalna udaljenost kao kriterij, a za uzorak u ovom istraživanju odrednica je bila povezanost te udaljenosti s horizontalnom udaljenošću jer su procijenjene i prednja i stražnja regija te implantati u susjedstvu zuba ili do drugog implantata.

Istraživanje Tarnowa i suradnika (12) te Choa i njegovih kolega (31) pokazala su da je, kad je udaljenost od kontaktne točke do koštanog grebena $\leq 5 \mathrm{~mm}$, interproksimalna papila uvijek bila prisutna. $U$ ovom istraživanju uočeno je da se to ne odnosi na regije između susjednih implantata te između zuba i implantata, jer u 48,7 \% regija koje su imale vertikalnu udaljenost $<5 \mathrm{~mm}$ nisu se pojavile papile. Dakle, važnost zubnih struktura za stvaranje interproksimalne papile evidentna je i parodontni biotip može imati važnu ulogu u tim nalazima.

Ocjenjujući prisutnost papile između zdravih zuba, Cho i suradnici (31) uočili su povezanost između udaljenosti od 
of the interproximal papilla is evident and the periodontal biotype may play an important role in those findings as well.

Evaluating the presence of the papilla between healthy teeth, Cho et al. (31) observed the correlation between the distance from the base of the contact point to the bone crest and the distance between the roots (horizontal distance) for the formation of the papilla. This association determines the interproximal space morphology. In the present study, the interproximal space morphology determined a $31 \%$ of papilla presence in narrow and short spaces, while the papilla was absent in $61.9 \%$ of the wide and long interproximal spaces.

The interproximal space morphology presented statistical significance among the groups evaluated in this study, demonstrating that the association between vertical and horizontal distances was an influencing factor for the presence or absence of the interproximal papilla. This fact demonstrates that for the planning of rehabilitations with osseointegrated implants, the association of vertical and horizontal distances may lead to a more satisfactory result for soft tissue esthetics in the interproximal regions.

Choquet et al. (35) described the presence of complete papilla in $58 \%$ of the interproximal regions between a tooth and an implant in the anterior region. In this study, $28.9 \%$ of the anterior tooth and implant regions had fully formed papilla. However, in the regions between the tooth and the posterior implant, a complete interproximal papilla was present only in $9.9 \%$ of them.

\section{Conclusion}

It was concluded that, in view of the investigated variables, the morphology of the interproximal space was the criterion that was most strongly associated with the presence or absence of the interproximal papilla. All other factors were observed and acted on the sample, but the morphology of the interproximal space that associates the vertical and horizontal distances was of great relevance.

From this observation, particular attention should be given to the planning phase of treatment with osseointegrated implants in order to observe all possible factors that may be associated with the formation of soft tissue between adjacent implants or between the implant adjacent to the tooth. In this way, the treatment process can be more easily performed and a more predictable prognosis can be given to the patient.

\section{Acknowledgments}

The Foundation for the Support of Science and Technology of the State of Pernambuco (FACEPE) for financial support, in the form of a Master's degree, awarded to Camila Agra Souza.

\section{Conflict of interests}

The authors report no conflict of interests. baze kontaktne točke do koštanog grebena i udaljenosti između korijena (horizontalna udaljenost) za stvaranje papile. Ta povezanost određuje interproksimalnu morfologiju prostora. $\mathrm{U}$ ovom istraživanju morfologija interproksimalnog prostora odredila je u $31 \%$ slučajeva prisutnost papile u uskim i kratkim prostorima, a nedostajala je 61,9\% širokih i dugih interproksimalnih prostora.

Morfologija interproksimalnog prostora imala je statistički značajnu ulogu među skupinama evaluiranima u ovom istraživanju, pokazujući da povezanost između vertikalnih i horizontalnih udaljenosti utječe na prisutnost ili odsutnost interproksimalne papile. Ta činjenica pokazuje da za planiranje rehabilitacije oseintegrajućim implantatima udruživanje vertikalnih i horizontalnih udaljenosti može rezultirati zadovoljavajućim estetskim rezultatom $s$ mekim tkivom u interproksimalnim regijama.

Choquet i suradnici (35) opisali su prisutnost potpune papile u $58 \%$ interproksimalnih područja između zuba i implantata u prednjem segmentu. U ovom istraživanju je 28,9 $\%$ prednjih zuba i implantata imalo potpuno oblikovane papile. No u regijama između zuba i stražnjeg implantata samo je $9,9 \%$ imalo kompletnu interproksimalnu papilu.

\section{Zaključak}

$S$ obzirom na promatrane varijable, morfologija interproksimalnog prostora kriterij je koji je najjače povezan s prisutnošću ili odsutnošću interproksimalne papile. Na uzorku su uočeni i svi drugi čimbenici, ali morfologija interproksimalnog prostora s vertikalnom i horizontalnom udaljenošću bila je važnija.

Na temelju dobivenih rezultata zaključujemo da veću pozornost treba posvetiti planiranju liječenja oseintegrirajućim implantatima kako bi se uočili svi mogući čimbenici koji mogu biti povezani sa stvaranjem mekog tkiva između susjednih implantata ili između implantata i zuba, čime se mogu postići predvidivi rezultati.

\section{Zahvale}

Velika hvala Zakladi za potporu znanosti i tehnologije države Pernambuco (FACEPE) za financijsku potporu magistarskom studiju koji je dodijeljen Camili Agra Souzi.

\section{Sukob interesa}

Autori navode da nisu bili u sukobu interesa. 
Sažetak

Cilj: Željelo se klinički i radiološki procijeniti čimbenike koji utječu na prisutnost ili odsutnost interdentalne papile između implantata i zuba ili drugog implantata. Materijal i metode: Uzorak je obuhvatio 44 pacijenta obaju spolova u dobi između 21 i 68 godina rehabilitirana sa 114 oseintegrirajućih implantata. U retrospektivnom kliničkom istraživanju podijeljeni su prema prisutnosti ili odsutnosti interproksimalnih papila kako slijedi: 1. skupina - nema papile, 2. skupina - djelomična papila, 3. skupina - potpuno oblikovana papila. Procijenjeni su uspješnost implantata, parodontni biotip te vertikalna i horizontalna udaljenost interproksimalnih područja. Rezultati: Od 114 implantata 46,5\% smatrano je neuspješnim, a krvarenje se pojavilo u $29,8 \%$ slučajeva. Parodontni biotip bio je u 85,1 \% regija tanak i valovit. Procjena skupina prema konfiguraciji interproksimalnog prostora pokazala je statistički značajnu razliku $(p=0,007)$, pri čemu je $61,9 \%$ širokih i dugih interproksimalnih prostora klasificirano kao skupina 1, a 31 \% uskih i kratkih interproksimalnih prostora uvršteno je u skupinu 3. Zaključak: Zaključeno je da je morfologija interdentalnog prostora čimbenik koji je najsnažnije povezan s prisutnošću ili odsutnošću interdentalne papile.
Zaprimljen: 16. lipnja 2019

Prihvaćen: 29. listopada 2019

Adresa za dopisivanje

Renata Cimões

University Cidade

Recife 50670-901, Brazil

Av. Prof. Moraes Rego, 1235

tel: +558121268817

renata.cimoes@globo.com

Ključne riječi

zubni implantati; gingiva; dentalna estetika

\section{References}

1. Chang LC. The association between embrasure morphology and central papilla recession. J Clin Periodontol. 2007 May;34(5):4326.

2. Belser UC, Schmid B, Higginbottom F, Buser D. Outcome analysis of implant restorations located in the anterior maxilla: a review of the recent literature. Int J Oral Maxillofac Implants. 2004;19 Suppl:30-42.

3. Chang M, Wennström JL, Ödman P, Andersson B. Implant supported single-tooth replacements compared to contralateral natural teeth. Crown and soft tissue dimensions. Clin Oral Implants Res. 1999 Jun;10(3):185-94.

4. Talwar BS. A focus on soft tissue in dental implantology. J Indian Prosthodont Soc. 2012 Sep;12(3):137-42.

5. Tarnow D, Elian N, Fletcher P, Froum S, Magner A, Cho SC, et al. Vertical distance from the crest of bone to the height of the interproximal papilla between adjacent implants. J Periodontol. 2003 Dec;74(12):1785-8.

6. Periodontology AAO. Glossary of Periodontal Terms. 4.

7. Ribeiro R, Melo R, Tortamano Neto P, Vajgel A, Souza PR, Cimões R. Polymorphisms of Il-10 (-1082) and RANKL (-438) Genes and the Failure of Dental Implants. Int J Dent. 2017;2017:3901368.

8. Tarnow DP, Cho SC, Wallace S. The effect of inter-implant distance on the height of inter-implant bone crest. J Periodontol. 2000 Apr;71(4):546-9.

9. Kawai E, Almeida A. Evaluation of the presence or absence of papilla between tooth and implant. The Cleft Palate-Craniofacial Journal 45(4): 399-406.

10. Shin S, Kye S, Hong J, Paeng J, Yang S. The effect of peri-implant bone exposure on soft tissue healing and bone loss in two adjacent implants. J Periodontal Implant Sci. 2012 Feb;42(1):20-4.

11. Pradeep A, Karthikeyan B. Peri-implant papilla reconstruction: realities and limitations. J Periodontol. 2006 Mar;77(3):534-44.

12. Tarnow DP, Magner AW, Fletcher P. The effect of the distance from the contact point to the crest of bone on the presence or absence of the interproximal dental papilla. J Periodontol. 1992 Dec;63(12):995-6.

13. Prato GP, Rotundo R, Cortellini P, Tinti C, Azzi R. Interdental papilla management: a review and classification of the therapeutic approaches. J Prosthet Dent. 2004 Nov;92(5):491-5.

14. Garber DA. The esthetic dental implant: letting restoration be the guide. J Am Dent Assoc. 1995 Mar;126(3):319-25.

15. Ferreira-Lopes MW, Gusmao ES, Alves RD, Rösing CK, Cimoes R. Effect of the distance from the contact point to the crestal bone on the degree of vertical loss of interdental papillae. Perio 5: 117 120.

16. Lops D, Chiapasco M, Rossi A, Bressa E, Romeo E. Incidence of inter-proximal papilla between a tooth and an adjacent immediate implant placed into a fresh extraction socket: 1-year prospective study. Clin Oral Implants Res. 2008 Nov;19(11):1135-40.

17. Salama H, Salama MA, Garber D, Adar P. The interproximal height of bone: a guidepost to predictable aesthetic strategies and soft tissue contours in anterior tooth replacement. Pract Periodontics Aesthet Dent. 1998 Nov-Dec;10(9):1131-41; quiz 1142.

18. Gastaldo JF, Cury PR, Sendyk WR. Effect of the vertical and horizontal distances between adjacent implants and between a tooth and an implant on the incidence of interproximal papilla. J Periodontol. 2004 Sep;75(9):1242-6.
19. Ochsenbein C, Ross S. A reevaluation of osseous surgery. Dent Clin North Am. 1969 Jan;13(1):87-102

20. Becker W, Ochsenbein C, Tibbetts L, Becker BE. Alveolar bone anatomic profiles as measured from dry skulls. J Clin Periodontol. 1997 Oct;24(10):727-31.

21. Weisgold AS, Arnoux JP, Lu J. Single-tooth anterior implant: a world of caution. J Esthet Dent. 1997;9(5):225-33.

22. Olsson M, Lindhe J. Periodontal characteristics in individuals with varying form of the upper central incisors. J Clin Periodontol. 1991 Jan;18(1):78-82.

23. Ainamo J, Bay I. Problems and proposals for recording gingivitis and plaque. Int Dent J. 1975 Dec;25(4):229-35.

24. Ong CT, Ivanovski S, Needleman IG, Retzepi M, Moles DR, Tonetti MS, et al. Systematic review of implant outcomes in treated periodontitis subjects. J Clin Periodontol. 2008 May;35(5):438-62.

25. Buser D, Weber HP, Lang NP. Tissue integration of non-submerged implants. l-year results of a prospective study with 100 ITI hollow-cylinder and hollow-screw implants. Clin Oral Implants Res. 1990 Dec;1(1):33-40.

26. Mombelli A, Lang NP. Clinical parameters for the evaluation of dental implants. Periodontol 2000. 1994 Feb;4:81-6.

27. Brägger U, Aeschlimann S, Bürgin W, Hämmerle, CH, Lang N. Biological and technical complications and failures with fixed partial dentures (FPD) on implants and teeth after four to five years of function. Clin Oral Implants Res. 2001 Feb;12(1):26-34.

28. Albrektsson T, Zarb G, Worthington P, Eriksson AR. The long-term efficacy of currently used dental implants: a review and proposed criteria of success. Int J Oral Maxillofac Implants. 1986 Summer;1(1):11-25.

29. Jemt T. Regeneration of gingival papillae after single-implant treatment. The International Int J Periodontics Restorative Dent. 1997 Aug;17(4):326-33.

30. Nordland WP, Tarnow DP. A classification system for loss of papillary height. J Periodontol. 1998 Oct;69(10):1124-6.

31. Cho HS, Jang HS, Kim DK, Park JC, Kim HJ, Choi SH, et al. The effects of interproximal distance between roots on the existence of interdental papillae according to the distance from the contact point to the alveolar crest. J Periodontol. 2006 Oct;77(10):1651-

32. Chen MC, Chan CP, Tu YK, Liao YF, Ku YC, Kwong LK, et al. Factors influencing the length of the interproximal dental papilla between maxillary anterior teeth. Breastfeed Med. 2017 Mar;12:103-109.

33. Cosyn J, Raes M, Packet M, Cleymaet R, De Bruyn H. Disparity in embrasure fill and papilla height between tooth- and implantborne fixed restorations in the anterior maxilla: a cross-sectional study.. J Clin Periodontol. 2013 Jul;40(7):728-33.

34. Kim JH, Cho YJ, Lee JY, Kim SJ, Choi JI. An analysis on the factors responsible for relative position of interproximal papilla in healthy subjects. J Periodontal Implant Sci. 2013 Aug;43(4):160-7.

35. Choquet V, Hermans M, Adriaenssens P, Daelemans P, Tarnow DP, Malevez C. Clinical and radiographic evaluation of the papilla level adjacent to single-tooth dental implants. A retrospective study in the maxillary anterior region. J Periodontol. 2001 Oct;72(10):1364-71. 